\title{
Summary and Afterword
}

\author{
By the Editors-in-Charge, \\ John A. Ryan, F. Ernest Johnson
}

$\mathrm{P}$

ERHAPS the average reader of this volume will look upon the title as inadequate. The first two sections may not seem to fit very appropriately under such a heading as "Industrial Relations and the Churches." The relation, indeed, is somewhat indirect. Nevertheless, it is real. In preparing this volume our main object has been to bring out the ethical and idealistic factors in the field of industrial relations. We have sought to ascertain in how far these factors are taking the place, or may be expected to take the place, of purely economic forces in the relations between employer and employee and between both of these on the one hand, and the community on the other hand. The functioning and the progress of ethical influences are due, surely in large part, to the teaching and the activity of the churches.

Although the papers represent a great variety and even a considerable opposition of viewpoints, they present a considerable and an encouraging amount of fundamental agreement. Indeed, it would not be misleading to say that the differences are of emphasis rather than of principle. No writer asserts that industrial relations should be governed by purely economic forces or by any conception, however euphemistically stated, of the so-called law of supply and demand. Substantially all the writers agree that the industrial conflict should be adjusted on the basis of ethical principles, and the majority appear to agree that the Church is directly and properly concerned with the conflict and its adjustment. This situation represents a vast improvement over that which obtained a half or even a quarter of a century ago. It is but a few years since the majority of employers, even those who were considered liberal by their contemporaries, regarded the employer-employee relationship as one of master and servant. Today, we find employers of a fairly conservative type committed to the principle of conference and to a definite participation on the part of the workers in determining the conditions of their working life.

\section{Progress Toward a Democratic Industrial ORDER}

The first step in this approach to a more democratic industrial order is found in the simple machinery of employee representation where a joint committee of management and men meets for a discussion of matters of mutual concern. Even where no actual power is held by the workers and where the matters open to discussion are limited to a very narrow field, the getting together of representatives of management and labor for a discussion of their several interests and a settlement of their differences, constitutes a definite approach to a more democratic, and a more ethical, industrial order.

The more liberal employers add to their acceptance of the principle of conference a recognition of the right of labor to large scale collective bargaining. So long as there are within our industrial order marked differences of property and power, there can be no 
full measure of justice to the workers if they are not given the privilege of full affiliation with the largest possible number of their fellows in their craft or their industry. When limited to a single establishment, even though it may be relatively large, collective bargaining confers no security upon the workers. It is only in the labor union with a large membership covering a wide territory and exercising definite power and influence in the craft or industry as a whole that the workers find economic security.

It may be contended that collective bargaining is not in itself a highly ethical performance; that it is a balance of forces rather than an interplay of moral influences. Yet industrial history shows that it is only when justice and security have been established that the higher forces of our collective life are liberated. Furthermore, there can be no doubt that the processes of collective bargaining have brought a great measure of intellectual development and moral discipline to the ranks of the wage earners.

It is now possible to discover evidences of the passing over of collective bargaining, and of those cruder processes and activities which are inevitably incident to trade unionism at a time when it is forced to struggle for existence, into a broader, freer and more generous interplay of intellectual and moral influences. There are a few examples in America of industrial organization in which the rights of the workers are secured by full recognition of the unions and where, at the same time, the solidarity of the establishment is maintained through a judicious plan of representation and self-government. Not only so, but in certain industries, notably in the clothing trades, a wise and generous coöperative policy has brought about the voluntary acceptance by labor organizations of definite responsibility for efficient production. To single out examples of this salutary tendency might seem invidious in a study of this kind, nor would the limitation of space permit their adequate treatment; but the person who is looking for evidences of moral progress in the industrial world will find a significant number of such demonstrations to challenge his attention.

As for the proper sphere of the Church in relation to industrial problems and controversies, the contributors to this volume make apparent a wide divergence of opinion. But that the principles of religion are susceptible of definite application to industrial problems, is scarcely any longer denied. The propriety of the entrance of churchmen, as such, and of religious organizations, into the field of research, with reference to particular controversies, is disputed by some clergymen and laymen of quite liberal mind. Yet it is probably true that the tendency is steadily toward approval of such undertakings, at least so long as other avenues leading to a full understanding of industrial facts and a fair appraisal of the issues involved are lacking.

It appears that in the immediate future the churches will be called upon to render more rather than less specific service in informing their people concerning industrial conditions and interpreting events in the light of their moral significance. It is certain, however, that the Church can successfully perform its mission only by maintaining a totally impartial attitude toward all the participants in controversy and by refraining, in the discharge of her prophetic duty, from those methods of strife and aggressive harshness whose evil effects in our industrial life it is one of the Church's chief tasks to remove.

It is gratifying to find writers of learning, judgment and experience, bearing 
testimony to the increasing part played by right and reason and the constraints of human fellowship in the settlement of industrial disputes and the currents of industrial development-testimony which amply justifies the recent efforts of the churches to raise these matters to a higher plane. The most fruitfu] lines of effort will doubtless be discovered in the course of the ministry of the local church to the workers in its own community. The measureless possibilities of such a ministry have been suggested in these pages. 